classes, enumerated on 1000 acres of each type; these tables give some idea of the large number of species which constitute the mixed type of rain forest as compared with the mora forest.

In Leaflet No. 3 of the same Department a note has been drawn up by Mr. R. L. Brooks, deputy conservator of forests, on "An Experiment on Air Seasoning of Native Timbers". Experiments with some of the native woods have been carried out under the supervision of Mr. Brooks, and so far as they have gone apparently justify the hopes of ultimate success. The imports of lumber into the Colony are high, and Mr. Brooks is definitely of opinion that they could be considerably reduced if stocks of seasoned local timber were made available.

\title{
Electrical Heresies
}

IN Stanford University Publications, University 1 Series, Mathematics and Astronomy, vol. 2, No. 1, Fernando Sanford, emeritus professor of physics, discusses terrestrial electricity and related topics. The volume, of 208 pages, is well produced and interestingly written; but it would form a very unsafe guide to knowledge. The author propounds views that he recognises as being very heretical, and bound to meet with a hostile reception; but it would be mistaken to be disarmed by his candour in this respect. His cardinal heresy is that "absolute electrical neutrality is unknown upon the earth, and could not be recognised if it were observed" (p. 71).

Prof. Sanford supposes that the ratio of the numbers of protons and electrons may be variable within wide limits upon different planets. In particular, he believes that the sun and earth possess large negative charges-large enough, in the case of the earth, to explain the magnetic field as a result of the daily rotation of the charge. $\mathrm{He}_{\theta}$ is aware of the familiar argument-simplest in the case of the sun-that the charge would be expelled by mutual repulsion and the outflow of electrons from the ionised solar atmosphere; but he denies that the electric charge upon a conductor exerts an outward pull upon the atoms of the conductor (though the experiment of an expanding charged soap-bubble would seem to indicate that they do), and that free electrons are held to the sun by gravitation alone. $\mathrm{He}$ asserts that electrons are apparently held to conductors by the pressure of the surrounding ether, which can sustain very great charges upon bodies. His positive arguments for the existence of a large solar charge are based on the supposed necessity for considerable charge-densities to explain the magnetism of sunspots, and also of the sun as a whole; also upon the electron gas theory of the solar corona, and on the supposed electrical repulsion of comets' tails-all of them being highly debatable matters, certainly not yet explained according to the generally accepted laws, but very unsuitable as foundations for a striking break-away from these laws.

Further, Prof. Sanford suggests that electrical repulsions between the sun and planets may produce planetary perturbations (particularly for Mercury), and that the daily variation of the charge induced upon the earth by the sun can be detected. His interpretation of his observations on this point is unlikely to gain favour, but the observations themselves might usefully be checked by other observers. Later chapters of the book deal with the electrostatic field of the earth, earth-currents and magnetic varia. tions, magnetic storms and solar activity, magnetic and electric influence of the moon, and barometric pressure and the earth's electric charge; to the reviewer they appear to abound with unlikely hypotheses.

\section{International Congress of Prehistoric and Protohistoric Sciences}

A PRELIMINARY outline of the arrangements A for the First International Congress of Prehistoric and Protohistoric Sciences, which is to be held in London, has been issued, and it is announced that in order to meet the convenience of foreign delegates the date of meeting will be Aug. 1-6, instead of July 25-30, originally arranged. The first meeting will be held on the afternoon of Aug. 1, and formal meetings will be continued during the week. The following week will be devoted to excursions to places of archæological interest. The Congress will meet under the presidency of Sir Charles Peers, Mr. R. Holland-Martin will act as treasurer, and the general secretaries are Prof. A. W. Brøgger and Prof. J. L. Myres. These appointments were made at the first meeting of the permanent council held in Paris in October last.

In accordance with a further decision of the permanent council, the work of the Congress will be divided into sections, arranged according to practical requirements rather than on strictly scientific lines. A classification of subject matter has been made for the first Congress, on the understanding that future division will be considered at the Congress. The following is the list of sections, with the names of the British archæologists who have been invited to act as presidents: Human Palæontology, the Origin and Evolution of Prehistoric Man (Sir Arthur Smith Woodward); Palæolithic and Mesolithic Periods (Mr. Reginald Smith); The Neolithic, Bronze, and Iron Ages in the Ancient World (Prof. H. J.
Fleure, Prof. J. L. Myres, Mr. Sydney Smith); The Neolithic, Bronze, and Iron Ages outside the Ancient World (Dr. H. S. Harrison and Prof. C. G. Seligman); The Passage from Prehistory to History (Mr. E. T. Leeds).

A number of questions has been placed on the agenda, although it is understood that communications on other matters may be offered, provided they come within the limits imposed by the statutes. Among the subjects specifically mentioned are the present state of our knowledge of fossil man, discoveries of human industries in the drift and the loess, the mesolithic question, the megalithic monuments, the problems of the copper and early bronze ages in western Europe, the origin of Mediterranean civilisations, the oriental basis of Egean chronology, Mediterranean contacts of the west European cultures of late bronze age and Hallstadt types, the Continental sources of racial and industrial types among the Anglo-Saxons, the origin and chronology of the Viking movements. Communications must be sent to the Secretary of the British Organising Committee, Society of Antiquaries, Burlington House, Piccadilly, London, W.1, before May 1, 1932.

Excursions have been arranged, to follow the Congress. They begin on Aug. 6, when those joining will be divided into two parties, of which one will stay at Oxford until Aug. 9, visiting the Rollright Stones, Wayland's Smithy, Uffington, etc., as well as the Ashmolean and Pitt-Rivers Museums. The second party will stay at Cambridge until Aug. 9, 
visiting Ipswich, Bramford, and Ely on one of the intervening days, and then proceeding to Oxford, where, after this party has inspected the Ashmolean and Pitt-Rivers Museums, the two parties will join to visit Salisbury and Devizes, returning to London on Aug. 11. An extended excursion, to take in the west of England, and lasting from Aug. 11 until Aug. 15, will be arranged for those who desire; or as alternatives, arrangements will be made for a visit to Ireland, to include Tara, New Grange, and Monasterboice; or to Scotland, to include inspection of the Scottish National Museum and prehistoric sites in the neighbourhood of Edinburgh.

The subscription to the Congress is $£ 1$ for members and $10 s$. for associates. Subscriptions should be sent to the treasurer of the Congress, at the Society of Antiquaries, Burlington House, Piccadilly, London, W.

\section{University and Educational Intelligence}

CAMBrIDGE.-The following grants have been made from the Worts Fund: $\mathfrak{£ 6 5}$ to L. S. B. Leakey (St. John's College) for the continuation of archæological and anthropological work in East Africa, $£ 50$ to A. Stephenson (St. Catharine's College) towards the expense of publication of the results of the British Arctic Air Route Expedition, $£ 30$ to R. B. Roberts (Emmanuel College) and W. V. Lewis (Gonville and Caius College) for cartographical work in Iceland, $£ 30$ to R. M. Jackson (St. John's College) towards the expenses of a geographical expedition to Spitsbergen, $£ 25$ to E. H. F. Baldwin (St. John's College) for biochemical research at Tamaris, £25 each to $\mathrm{P}$. W. Richards (Trinity College) and P. M. Synge (Corpus Christi College) for botanical research in Sarawak, $£ 20$ to S. R. Nockolds (Trinity College) for geological research at Carlingford.

The following have been elected to fellowships at King's College: Mr. L. Bairstow, scholar, who was placed in Class I. Part I. 1927 and in Class I. Part II. 1928 of the natural sciences tripos, as S. H. Ehrman fellow; Dr. H. C. Darby, scholar of St. Catharine's College, University lecturer in the faculty of geography, who was placed in Class I. Part I. 1926 and in Class I. Part II. 1928 of the geographical tripos.

EDINBURGH.-The Senate has resolved to offer the honorary degree of LL.D. to the following, among others : Prof. C. Vernon Boys ; Mr. David Middleton Greig, Royal College of Surgeons, Edinburgh; Dr. R. Stewart MacDougall, formerly reader and Steven lecturer in agricultural and forest entomology in the University of Edinburgh; His Excellency Andrew Mellon, United States Ambassador, London; Prof. Arthur Robinson, emeritus professor of anatomy in the University of Edinburgh; the Right Hon. Sir Archibald Sinclair, Secretary of State for Scotland; and Sir Josiah Stamp.

LEeDs.-Prof. J. W. Harvey, at present professor of philosophy in the University of Durham (Armstrong College), has been appointed professor of philosophy, in succession to Prof. C. M. Gillespie, who retires at the end of the present session. Prof. Harvey was educated at Bootham School, York, at Rugby, and at Balliol College, Oxford. He took a first class in classical honour moderations in 1909 and a first class in the final Lit. Hum., 1911. He was lecturer in philosophy in the University of Birmingham from 1912 until 1927 , when he was elected to the chair of philosophy at Armstrong College.

Liverpool.-At the meeting of Council on March 13 it was agreed to confer the honorary degrees of M.Eng. and M.Sc., on July 2, on Mr. H. H. Harrison and Mr.
W. Horton respectively. Mr. Harrison has published works on steam turbines, boiler feed injectors, and the historical basis of modern telegraph printing. Mr. Horton has been honorary lecturer in plant histology in the University during the past ten years, and has distinguished himself by his investigations on the technical methods of histology and, in particular, by his work on the preparation of knife edges and the critical angles in the sectioning of waxes.

Prof. Herbert E. Roaf, professor of physiology in the London Medical School, has accepted the George Holt chair of physiology in the University as from Oct. 1, in succession to Prof. J. S. Macdonald, who retires at the end of the present session. Prof. Roaf was in succession Johnston colonial fellow, assistant lecturer in physiology, and lecturer in chemical physiology in the University of Liverpool. From 1911 until 1920 he was lecturer in physiology at St. Mary's Hospital Medical School, London.

Prof. A. H. Sturtevant, professor of genetics at the California Institute of Technology, will lecture at the University of Birmingham during the autumn term of this year. $\mathrm{He}$ will be in residence at the University of Leeds on Jan. 5-March 18, 1933, and afterwards proceed to Armstrong College, Newcastle. The lectures have been arranged in connexion with the scheme of the Carnegie Endowment for Industrial Peace, by which certain American professors will spend a year visiting universities in Great Britain.

THE directors of higher education from a number of different countries have just met, for the first time, at the International Institute of Intellectual Co-operation for the purpose of discussing various questions of great importance in the organisation and functioning of their university systems. The following were present: M. Jacques Cavalier (France), M. Ugo Frascharelli (Italy), Sir Frank Heath (British Empire), Prof. Zoltan de Magyary (Hungary), Prof. Werner Richter (Germany), and Dr. Horatio Krans (American University Union in Europe, observer). The committee drew up a comprehensive programme for future work, envisaging, more particularly, agreements concerning university exchanges and the overcrowding of universities and of the liberal professions.

The Ministry of Agriculture and Fisheries is offering five senior scholarships tenable at agricultural colleges or university departments of agriculture for diploma or degree courses in an agricultural subject, and 130 junior scholarships (including 10 extended junior awards for those who have already held junior scholarships) tenable at farm institutes for courses in agriculture, horticulture, dairying, or poultry husbandry. The awards are confined to sons or daughters of agricultural workers and bona fide workers in agriculture. Forms of application and other information may be obtained from the Secretary, Ministry of Agriculture and Fisheries, 10 Whitehall Place, London, S.W.1, or from the offices of county councils. The latest date for receiving applications is April 30 .

A LIMITED number of fellowships are being offered by the Salters' Institute of Industrial Chemistry to chemists of post-graduate standing. The object of the fellowships is to afford additional and special training preparatory to a career in industrial chemistry. The normal value of each fellowship is from $£ 250$ to $£ 300$. The Institute also offers a limited number of grants-in-aid to young men or women, not under seventeen years of age, employed in chemical works in or near London, who desire to extend their education for a career in chemical industry. Applications for the fellowships and grants-in-aid must be sent not later than May 1 to the Director, Salters' Institute, Salters' Hall, St. Swithin's Lane, E.C.4. 